\title{
Putting Neoliberalism in its Place
}

\author{
COLIN CROUCH
}

\begin{abstract}
Neoliberalism is not as popular as its opponents seem so much to fear; in democratic politics it nearly always hides behind other ideologies and policy types, as its essential message that we should pursue no goals that cannot be achieved through the market is intrinsically unattractive to the majority of people. Its power lies in the wealth of its key supporters, and in the difficulty of raising coordinated opposition to it among post-industrial populations that have little sense of their political interests. The main base for hope of change in this comes from the as yet unrealised potential of women's movements.
\end{abstract}

Keywords: Neoliberalism, markets, social democracy, democracy, gender

Social democrats everywhere continue to be mesmerised by neoliberal politics. Anxiety over the enormous corporate lobbying power behind these policies is perfectly justified, but centre-left politicians have also convinced themselves that the neoliberal project is popular, and that it has a monopoly on economic efficiency. They therefore cower before it, seeking a few corners where they might proffer some minor alternatives rather than confronting it. This is unnecessary, and needs to be replaced by both a bolder attack on neoliberalism itself and assertion of new versions of social democracy. ${ }^{1}$

First, some definitional clarifications: by neoliberalism I understand that political stance that claims that markets will virtually always be more effective than governments (or indeed almost all other institutions). By social democracy I mean that political stance that holds that most people will be unable to realise their various goals through the market alone and will at times even be threatened by the market. A democratic state must therefore be ready to respond to citizens' needs with a wide variety of actions, regulations and services, ensuring that these are not the preserve of those wealthy enough to provide for themselves through the market alone.

\section{The democratic deficit of neoliberalism}

Neoliberalism has become globally dominant because it has captured the minds (and feeds the wallets) of political, economic and many other elites, not because it has become an irresistible democratic force. With the current exception of the Dutch People's Party for Freedom and Democracy, political parties that have little to offer other than a neoliberal agenda are usually fairly small minority parties-such as the Free Democrats in Germany, which has now lost its representation in parliament. Where neoliberal ideas achieve a stronger status it is because they form coalitions with movements able to build on deep roots in the electorate-usually conservative or Christian parties. Even in the USA neoliberals have to make common cause with fundamentalist Christians and groups with implicit ethnic agendas within the Republican Party, political ideologies with which they have little in common. Sometimes, as with Clinton's New Democrats, Blair's New Labour or Schroeder's Neue Mitte, the partners are social democratic; alliances with the traditional centre-right are more likely, however, as these are far more likely to share neoliberals' rejection of redistribution and a strong welfare state.

People might like some of the vulgarised slogans that can be abstracted from neoliberalism: taxes should be lower; there should be less 'red tape'; people should be forced to work rather than claim benefits. But that makes for a limited, negative agenda. Neoliberalism's central positive contention is not just that the market is always a better guide to public welfare than anything that 
can be attempted through political action, but also that values, interests, prejudices should only be expressed in ways that can be realised through the market. Those that cannot must either be transformed into market form or fall by the wayside. Very few people are willing to accept this restriction, except perhaps those rich enough to buy the practical realisation of any ideas or values that they hold. For example, culture and education have to be justified in terms of their economic contribution, unless they become the hobby of a wealthy philanthropist. While there are many such instances of such thinking in contemporary public policy, the core belief of neoliberalism that lies behind them is rarely expressed baldly in political debate. Neoliberals prefer to work behind the scenes. They find democracy potentially very disturbing and try to limit its reach-as Wolfgang Streeck and Philip Mirowski have recently demonstrated in their separate, excellent analyses of the political ideas of Friedrich von Hayek. $^{2}$

Further, although the public rhetoric of neoliberals is couched in terms of markets, the freedom of choice and restrictions of government power that they bring, in practice they mostly imply 'large corporations' whenever they say 'markets'. This is partly because it is impractical to have a pure market with masses of producers in many key sectors of the economy. As I have tried to show elsewhere in a discussion of the decline of antitrust law, neoliberal economic ideas have adapted themselves to this reality by arguing that markets dominated by quasi-monopolies can serve consumer welfare better than those with large numbers of producers, because size equals efficiency. ${ }^{3}$ Many economists have challenged that equation on efficient market grounds, but there are other problems. The crucial idea of 'freedom of consumer choice', one of neoliberalism's few popular slogans, comes to be supplanted by the top-down notion of 'consumer welfare' as determined by corporate leaders and competition courts.

One of the ideals of a true market economy with no dominant firms is that no producers should wield a corrupting influence on politics. Once fortunes made in the economy can be deployed politically, the assumption of rough equality of political influence that is fundamental to liberal democracy falls. Once neoliberals uncritically accept that role for wealth they have ceased to be true to the classical economic ideals of Adam Smith, as well as revealing themselves not to be true allies of democracy. The think tanks, movements and parties that most uncompromisingly promulgate neoliberal ideas depend heavily for their strength and influence on lavish funding from foundations having their bases in large corporate and personal fortunes. This extends to ostensibly grass-roots movements like the Tea Party, so aptly dubbed by Mirowski an 'astroturf' movement. $^{4}$

\section{Markets and diversity}

In these different ways, the claim to democratic plausibility of neoliberalism is highly vulnerable to attack, but this should not be read as a rejection of the idea of a market economy, or even of the idea of intensifying the role of the market where it can improve efficiency and true consumer choice. Social democrats do not need to be on the defensive when the advantages of a market economy are extolled over a state-controlled one, as they do not advocate state control, just state correction of the defects of the market. For decades now we have had massive real-life experiments that enable us to see the difference between economies run largely on market lines and those where markets are marginalised. Compare both the economic and political conditions of East and West Germany in 1989, or North and South Korea today. Suppression of markets, even if not produced by dictatorships, will soon produce them, as no resources come free from the hands of politicians and officials in societies with very limited markets.

What really matters here is the scope for diversity and innovative challenge within a political economy. Its insistence on conformity in ideas of all kinds and its monolithic state ownership patterns were the fundamental flaws of state socialism that produced its incompetent drabness. But today neoliberalism risks doing the same. A market economy will never become as bereft of innovative capacity as a state-controlled one, because there are always some free-floating resources, but a fully neoliberal society (i.e. one where both economy and polity are dominated by 
neoliberal orthodoxy) would lose its capacity for change. Change comes through challenge and the confrontation of opposed, or at least different, backgrounds and perspectives. Once that ceases there is stasis, and in the case of total dominance by neoliberal orthodoxy, the deep ambivalence of Hayek and others about the rights of democracy can start to work a wider mischief.

In the strictly economic field, innovators are often outsiders of various kinds: immigrants, the religiously unorthodox, alternative people of various kinds. As they become successful and their corporations grow, these characteristics are often left behind, but they were crucial to their beginnings. Neoliberalism can sustain this kind of diversity-led innovation within the economy-provided its need to make alliances with other political tendencies does not lead it into coalitions with xenophobic and other intolerant right-wing tendencies within or between parties. But at the level of politics and society, what stimulating challenges await neoliberalism itself once it has disposed of all opposition to its project? While it extols the role of competition and freedom of choice in the economy, and while many of its leading protagonists believe in extending the reach of the market and analogues for it into virtually all walks of life, it does not extend this logic to ideologies and policy approaches. Here neoliberals seek a complete monopoly, guaranteed indeed by a state safely in their own hands and with many public institutions placed beyond the reach of democracy. This is where twentieth and twentyfirst-century neoliberalism is such a narrow shadow of its eighteenth and nineteenthcentury predecessor, classic liberalism. This welcomed diversity and innovation in all areas of life. True, the clashes provoked by this openness produced some bloody conflicts, from 1789 and 1948 onwards, but its long-term legacy was to liberate our lives and minds across a whole range of matters, not just our ability to choose goods and services.

Once the people of today's advanced democracies gave up using violent struggle to resolve political conflicts, the abiding legacy of classic liberalism was to allow a continuing clash between rival world-views. Sometimes these result in dull stalemates, but often they lead to creative compromises. The part of the world where we see this most clearly is the
Nordic countries, where so many initiatives in economy, polity and society have originated. It is normal on the left to attribute Nordic successes to their past prolonged periods of social democratic political dominance. I interpret it differently. These were also seriously market-oriented economies: small, open, dependent on world trade for many of the means of modern life and therefore needing to be able to export competitively. Powerful trade unions and social democratic parties were forced to develop forms of market regulation that were at least compatible with, and eventually came positively to advance, competitiveness. The economies remained primarily in private hands; in the Swedish case in particular, the economy was dominated by major firms that became global. Creative compromise between opposed political forces, neither social democratic nor neoliberal hegemony, were at the heart of the model, where today economic performance continues to be among the best in the world while the welfare states remain the world's most generous and the levels of inequality among the world's very lowest. Social democracy represented the culmination of liberalism's programme; the alternative project of total socialist dominance produced little more than stagnation, a police state and an inability to adapt that finally led to its total collapse.

This last point constitutes a case against unchallenged dominance by any one political force. The specific case against such dominance by neoliberalism is that made at the outset: people cannot be forced to accept that their only legitimate values are those sanctioned by the market. As Karl Polanyi showed in his great study of the English enclosure movement, ${ }^{5}$ the introduction of markets tore into an existing social fabric, damaging forms of solidarity and social support developed over long periods. Modern social policy developed to provide new forms of protection, given the failure of the market to provide adequate solutions itself. Similar processes have returned at various historical moments. We are living through another one now, as marketisation, especially in its globalising form, breaks down national economic arrangements, the twentieth-century welfare state and even the mechanisms in the natural world that have protected our climate and physical environment. These varied incur- 
sions of the market into other aspects of life require a diversified response, depending on one's particular values and associated interests. We might be pleased at the demise of national systems of economic protection, but when it comes to plunging relatively poor people into anxiety and insecurity over their livelihoods or provoking natural disasters through climate change, many of us will take a different approach.

However much we might disagree over an exact list of preferences and priorities in confronting the invasions of the market, very few people are really willing to delegate everything to the market in the way that true neoliberals do. For them, no other human institution-least of all that institution charged with surveillance of common interests, the state-has an accumulation of information, competence and efficiency to match that of the market - and, they have to add, the great corporations, though their theoretical basis for that argument is far less elegantly grounded than that of the pure market itself. For them, if a particular goal cannot be achieved through the market, then by definition its pursuit is either inefficient or not wanted by enough people. They have a major problem with market externalities, those issues that are affected by a market exchange but which do not enter into the cost calculations of the buyers and sellers involved; most cases of pollution and environmental damage fall into this category. Neoliberals deal with these problems in three ways. Often they insist that left-wing critics exaggerate the importance of an externality in order to undermine the capitalist system in the interests of its enemies. This is an important strand in the argument of climate-change deniers.

Second, they will argue that if consumers of a product cared enough about an externality, they would include that in their purchasing decisions just as they might any other matter of taste. For example, if people care about the environmental friendliness of oil extraction and processing, they will avoid the products of firms known to have poor environmental records. That argument is not to be entirely ignored. Provided consumers have adequate and truthful information about such issues, much might be achieved in this way, as the wave of environmental details provided in much contemporary product information shows. However, the neoliberal response assumes that no issue external to the strict terms of market transactions, even one as vast as climate change, can have an importance greater than that given to it by consumers as a matter of taste. It is very doubtful that this is widely acceptable.

More contentious still are the claims that the economic calculus can be extended to virtually all areas of life-most strikingly, in the arguments of Gary Becker, that even family relationships can be subsumed within market analysis. ${ }^{6}$ In other words, all our relationships and values can be reduced to cost calculations; love, for example, not only always has its price, but will be better off for being so regarded. Only a very brave politician would assert that publicly.

The key lesson is that the more we extend the role of markets, the more we damage interests, values and people that cannot protect themselves through the market itselfunless those values and interests can be fully redefined in market terms. Therefore, the more we have a marketisation project, the more we need a politics that can reflect on its consequences. Which aspects of this damage should be simply accepted, even welcomed? Which should be accepted, but with recognition that the victims should be compensated in some way? (For example, if marketisation is producing increased inequality, should there be increased taxation on high incomes? If labour markets are becoming more flexible, should there be improved income support for those temporarily thrown out of work?) In other cases again, damage may seem so severe that it should be reduced by attempts at regulating the market behaviour concerned (irresponsible banking behaviour and environmental damage resulting from economic activity would be examples here.) There are no technical solutions to these questions; they are the appropriate business of political conflict. Neoliberalism tries to prevent us from considering those conflicts by placing the market order beyond democratic political bounds.

There are major issues here for European Union policy-makers. The European project has always been primarily a market-making one, initially breaking down barriers to commerce across national boundaries and ensur- 
ing that member states traded with each other on reasonably level playing fields. But this has usually been accompanied by some, though limited, market-correcting measures, including in the area of social policy. Currently, however, the market-correcting aspects have been forgotten, and we have moved into a period of aggressive European marketisation without social policy rebalancing. A major instrument of this has been the extension of the single market to the services sectors, which is making it increasingly difficult to defend public services from privatisation. The crisis has intensified this, which is ironic given that it was caused by the behaviour of banks rampaging through the deregulated financial markets that have been a key part of the global neoliberal project. Fears of economic stagnation lead politicians to conclude that only even more market deregulation can liberate economic dynamism. As part of this, Europe has given up its leading role in combating climate change. The policies that the EU, with others, has imposed on the problem economies of the euro zone call overwhelmingly for the exposure of workers to radical insecurity. There is now a growing danger that marketisation and compensation for it will become a division of labour between European and national policies respectively. This will not help a fundamental challenge facing social policy: can it protect a purely national determination at a time when market-making is a global project beyond nations' reach?

In the UK this problem takes a particularly subtle form, the issue of the respective roles of the EU and the nation-state in marketisation and policies to contain it being seen the other way round. Romantic Conservatives attack the EU by demanding that Britain should have unimpeded national sovereignty. But national sovereignty can achieve little in a globalised economy dominated by transnational corporations. Therefore, to confine political action on economic issues to the nation state is to condemn it to impotence. This is of course what neoliberals seek, but are reluctant to say too openly. However, in the UK they can advance their goal while appearing to be proposing the exact opposite by hiding behind nationalist flag-waving. As ever, neoliberalism hides behind other, often incompatible, political forces.

\section{Finding a social base for opposition}

I have argued that economic, political and social dynamism depend on permanent challenge and peaceful confrontation of opposed class interests. Today the organised industrial working class that, probably without many of its members ever appreciating what they were achieving, secured the creative compromises that in many countries characterised the second half of the twentieth century, is in steep decline. True to what one should expect, in the absence of an alternative representative of major social interests outside the economically privileged, this decline is being accompanied by the rise to power of a new, uncompromising form of hegemony favouring the interests of the privileged. Neoliberalism is not however achieving an easy triumph; it is not overrunning abandoned trenches of the welfare state, but meeting resistance at many points.

The problem is that these forces of resistance are disparate and lack strategy. Karl Marx was wrong to see the industrial proletariat as the class to end all classes, but it is not easy to see what comes after it. The great majority of people are not often politically active. Why should they be? Their chances of exercising any real influence remain close to zero unless they make pursuit of a political career the overwhelming focus of their lives; even then their chances of success remain small. Therefore their acquisition of a coherent political identity can never be taken for granted. Where such identities exist, they have been the result of particular historical processes, not some logical necessity. The achievement of universal democratic citizenship proceeded through a number of struggles over inclusion and exclusion. Groups identified on the basis of civil wars, religion, property ownership or type of work would be defined as excluded, which conferred a political meaning to their identity. Those included also acquired an identity as the included, and usually concluded that they should support the leaders of their identity in maintaining the exclusion of the others; vice versa for those excluded. This process came to a halt once universal political citizenship was achieved. Since that time, newly emerging identities, such as those occupational ones that have 
developed in the post-industrial economy, have not needed to struggle for inclusion; therefore they confer no sense of political identity. The dynamic process of identity formation through struggle has come to an abrupt end. The political landscape formed by our major parties comprises extinct volcanoes, survivors of an active past of religious and class struggles. By a curious irony the very process that finally ushered in mass democracy, universal citizenship, also undermined the basis of its continuing vitality.

There are two main exceptions: one dangerous, the other promising. These are race and gender. Major struggles over the inclusion and exclusion of immigrants and ethnic minorities become increasingly important, as discussed above. But conflicts over small minorities are not the stuff of major, productive social compromises. It is no coincidence that, after decades of the opposite being the case, partisan conflict in the USA is today far more intense than that in almost all Europe. A wide diversity of ethnic minorities makes up a far larger proportion of the US population than they do of most European countries; indeed, in using the term 'ethnic minority' I am inappropriately applying a European concept there. Ethnic conflict as such is too dangerous to be at the explicit centre of conflict, but it hides behind much of the political mobilisation of religious identities that today so strongly marks US politics off from European. True, the USA is the world headquarters of neoliberalism, and there is not much connection between market ideology and religious belief; as we have noted, though, neoliberalism always needs allies for its public face.

The second and more encouraging identity is gender. Women possess four major characteristics that make them suitable candidates to be the carriers of a major, constructive challenge to neoliberal hegemony. First, and most simply, they are not a minority. Second, although they long ago acquired political citizenship, they still suffer from a range of gender-based disadvantages in participating fully in life outside the home alongside men. Their identity therefore has a powerful political dimension. The fact that several of these disadvantages have been addressed in many countries in recent years does not weaken the force of this. History has frequently shown us that disadvantaged groups are most likely to press for change when they see some signs of improvement. Hopelessness does not create activism. Third, women constitute the majority of people working in middle and lower positions in the service sectors of the economy, the very social location to which one must look for any new challenge to dominance by elites. ${ }^{7}$

Finally, and more difficult to demonstrate than these three points, women are, by both the long-term and the recent distinctive history of the lives of a large majority of them, better equipped than the majority of men to resist the central thrust of the neoliberal project. Until now, there has not been much evidence of this outside some not very well known feminist literature. This is mainly for two reasons. First, most successful policies for women's advance have been a shared neoliberal and social democratic agenda, against gradually shrinking conservative opposition, for liberation from various constraints imposed by past law and custom. Except when it comes to demands for state support of childcare, neoliberals have no problems with this. If anything, social democracy might have been more threatened as its traditional male bastions in the workforce were invaded, but the fact that, particularly in the more social democratic societies, women tended to work in occupations-especially in the care sector-where there were few men has rendered this unimportant in practice. A second factor has been that, in order to be successful in achieving leadership positions in most types of organisation, women have had to adapt themselves to stereotypically male approaches to work and life.

It is in relation to this second point that we should look for a stronger challenge to neoliberalism from women. Neoliberalism requires of members of society, if they are to avoid abject failure, a single-minded devotion to maximising interests that are defined according to a strict economic calculus. Areas of life that lie outside the scope of that approach are either to be ignored or forced to be redefined so that they can take their place within that calculus. I do not believe that many people of either gender can accept this over the long haul, but men are more likely to adapt to it. To express the point politely, men are more used to the single-minded pursuit of work goals at

Putting Neoliberalism in its Place 119 
the expense of family life, friends and relationships. To express the same point impolitely, men are on average further towards the autistic end of the spectrum of character types. Neoliberalism, with its insistence on a single, non-social form of communication, the emission of market signals via numbers, is an essentially autistic ideology. The dual role that women usually play in contemporary society, balancing work and home, places them at the sharp end of these struggles. If gender relations become more balanced, then an increasing number of men will take this role too-a convergence on a hitherto predominately female life that is important to what I mean by a politics increasingly defined by women but benefiting many men too.

Some aspects of this are readily understandable and turned into familiar political demands. For example, we need a politicisation of the problem of work/life balance, talked about by very many people but not by political parties. ${ }^{8}$ But there are deeper aspects that will become more pressing as the neoliberal strategy itself achieves more victories. For example, as Mirowski has demonstrated, the marketisation of everything eventually requires a fragmentation of the self. ${ }^{9}$ In a highly flexible neoliberal economy where eventually all support for the unemployed will have been withdrawn, people need to be repeatedly re-presenting and redefining themselves to be attractive to employers' constantly changing requirements. This is especially true in the personal services sectors (where women predominate), where the self becomes part of the product. To present oneself effectively against a constantly shifting set of criteria requires constant attention to the signals one gives out by one's entire lifestyle-and therefore in one's life as a consumer, as in a fully marketed society there is little outside the realm of purchase and consumption. As Mirowski puts it:

When agents are endlessly desperate to refashion themselves into some imaginary entity they anticipate that others want them to be, the supposed consumer sovereignty the market so assiduously pampers has begun to deliquesce. It is a mug's game to trumpet the virtues of a market that gives people what they want, if people are portrayed as desperate to transform themselves into the type of person who wants what the market provides. ${ }^{10}$
We are all affected by this; the great majority of us will resent it once we are old enough to wonder if there is more to life than Facebook. But if it is to be politicised and become part of a revulsion against neoliberalism, the move will come first from women, as they are hit by it most directly and fully. It will be a demand for the protection of whole areas of life and the self from the market, which in turn requires that the market cease to be the main arbiter of value, right across the board of social life. There are further issues. Some observers have argued that an economy dominated by women would have a different character from the male one that we now experience. ${ }^{11}$ How far one takes these arguments is not yet clear, but it opens intriguing possibilities. Given that men usually form the majority of support for the new racist populist parties, the possibility arises of a new genderbased politics whereby mainly female social democratic movements confront mainly male xenophobic ones, with neoliberals caught awkwardly between them.

The large political movements that have dominated the democratic world have to redefine themselves from time to time, reaching out to new kinds of support while somehow keeping hold of old ones, managing to have multiple roots that enable them to be simultaneously weighty and adaptable. The British Conservative party managed to change from being the protectionist defender of rural interests to the free-trade spokesman of the financial sector. European Christian parties changed from orchestrators of intolerance to mild advocates of ecumenicalism. Social democratic parties throughout Europe have already made a transition from being mainly supported by male manual workers in manufacturing to securing more than 50 per cent of their votes from women, especially those working in the care sector. US Democrats have had a similar experience. Almost everywhere in the advanced world, the majority of trade union members are now women. The adaptation of social democracy to being a movement that primarily represents women's concerns in the new economy is already underway. It needs only to become more imaginative. It is in social democracy's existing repertoire of policies, combining acceptance of the market where it helps achieve our goals with social policy, regulation and action 
by social partners and other non-state, nonmarket groups in order to check it, that we shall find responses to this emerging political imperative to protect the human self from the insistent invasion of the market and the giant corporation, and to insist that the market cannot be the only institution through which we pursue human values.

\section{Notes}

1 I have tried to do this at greater length in C. Crouch, Making Capitalism Fit for Society, Cambridge, Polity, 2013.

2 M. Mirowski, Never Let a Serious Crisis Go to Waste, London, Verso, 2013; W. Streeck, Gekaufte Zeit, Berlin, Suhrkamp, 2013.

3 C. Crouch, The Strange Non-Death of Neoliberalism, Cambridge, Polity, 2011.

4 Mirowski, Never Let a Serious Crisis Go to Waste.

5 K. Polanyi, The Great Transformation: The Political and Economic Origins of Our Time, Boston, Beacon Press, 1944.

6 G. Becker, Human Capital, Chicago, University of Chicago Press, 1964.

7 For a full account of the class position of women in advanced societies, see D. Oesch, Redrawing the Class Map: Stratification and Institutions in Britain, Germany, Sweden and Switzerland, Basingstoke, Palgrave Macmillan, 2006.

8 For a good review of work-family conflict as it affects European societies during the crisis, see F. McGinnity and H. Russell, 'Work-family conflict and economic change', in D. Gallie (ed.), Economic Crisis, Quality of Work \& Social Integration: The European Experience, Oxford, Oxford University Press, 2013, pp. 169-94.

9 Mirowski, Never Let a Serious Crisis Go to Waste, ch. 3.

10 Ibid, p. 115.

11 U. J. Heuser and D. Steinborn, Anders denken! Warum Ökonomie weiblicher wird, Munich, Hauser, 2013. 